\section{Biofouling}

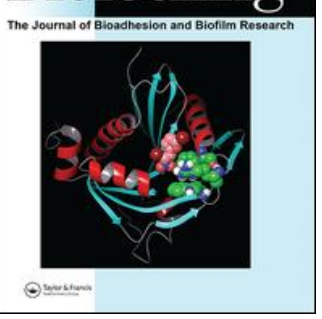

Biofouling

The Journal of Bioadhesion and Biofilm Research

\title{
Antibacterial activity of a novel antimicrobial peptide [W7]KR12-KAEK derived from KR-12 against Streptococcus mutans planktonic cells and biofilms
}

B. R. da Silva, A. J. S. Conrado, A. L. Pereira, F. F. V. Evaristo, F. V. S. Arruda, M.

A. Vasconcelos, E. N. Lorenzón, E. M. Cilli \& E. H. Teixeira

To cite this article: B. R. da Silva, A. J. S. Conrado, A. L. Pereira, F. F. V. Evaristo, F. V. S.

Arruda, M. A. Vasconcelos, E. N. Lorenzón, E. M. Cilli \& E. H. Teixeira (2017) Antibacterial activity of a novel antimicrobial peptide [W7]KR12-KAEK derived from KR-12 against

Streptococcus mutans planktonic cells and biofilms, Biofouling, 33:10, 835-846, DOI: 10.1080/08927014.2017.1374378

To link to this article: https://doi.org/10.1080/08927014.2017.1374378

冊 Published online: 02 Oct 2017.

Submit your article to this journal $[\pi$

LII Article views: 483

View Crossmark data $[\pi$

Citing articles: 2 View citing articles \ulcorner 


\title{
Antibacterial activity of a novel antimicrobial peptide [W7]KR12-KAEK derived from KR-12 against Streptococcus mutans planktonic cells and biofilms
}

\author{
B. R. da Silva ${ }^{a, d}$, A. J. S. Conrado ${ }^{a}$, A. L. Pereira ${ }^{a}$, F. F. V. Evaristo ${ }^{a, b}$, F. V. S. Arruda ${ }^{a, b}$, M. A. Vasconcelos ${ }^{a, e}$, \\ E. N. Lorenzón ${ }^{f}$, E. M. Cillic and E. H. Teixeira ${ }^{a}$
}

aDPML/LIBS, Integrated Laboratory of Biomolecules, Federal University of Ceará, Fortaleza, Brazil; 'bSchool of Dentistry, Faculdades INTA, Sobral, Brazil; Institute of Chemistry, Universidade Estadual Paulista (UNESP), Araraquara, Brazil; dSchool of Dentistry, Universidade de Fortaleza -

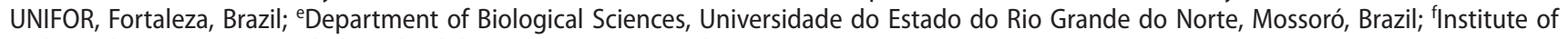
Biological Science, Universidade Federal de Goiás, Goiânia, Brazil

ABSTRACT

The aims of this study were to describe the synthesis of a novel synthetic peptide based on the primary structure of the KR-12 peptide and to evaluate its antimicrobial and anti-biofilm activities against Streptococcus mutans. The antimicrobial effect of KR-12 and [W $\left.{ }^{7}\right]$ KR12-KAEK was assessed by determining the minimum inhibitory (MIC) and minimum bactericidal (MBC) concentrations. The evaluation of anti-biofilm activity was assessed through total biomass quantification, colony forming unit counting and scanning electron microscopy. [W ${ }^{7}$ KR12-KAEK showed MIC and MBC values ranging from 31.25 to 7.8 and 62.5 to $15.6 \mathrm{\mu g} \mathrm{ml}^{-1}$, respectively. Furthermore, [W7]KR12KAEK significantly reduced biofilm biomass (50-100\%). Regarding cell viability, $\left[\mathrm{W}^{7}\right]$ KR12-KAEK showed reductions in the number of CFUs at concentrations ranging from 62.5 to $7.8 \mu \mathrm{g} \mathrm{ml}^{-1}$ and 500 to $62.5 \mu \mathrm{g} \mathrm{ml}^{-1}$ with respect to biofilm formation and preformed biofilms, respectively. SEM micrographs of $S$. mutans treated with $\left[\mathrm{W}^{7}\right]$ KR12-KAEK suggested damage to the bacterial surface. $\left[\mathrm{W}^{7}\right] K R 12-\mathrm{KAEK}$ is demonstrated to be an antimicrobial agent to control microbial biofilms.
ARTICLE HISTORY

Received 21 February 2017

Accepted 24 August 2017

KEYWORDS

Antimicrobial peptide; Streptococcus mutans; biofilm; dental caries

\section{Introduction}

The term 'dental caries' was introduced in the literature in approximately 1634 to describe the holes generated in teeth; these holes were subsequently associated with the severe pain and tooth loss caused by the disease (Bowen 2015). However, when the term was introduced, no knowledge about the pathophysiology of the disease was known. Currently, it is known that dental caries are considered a multifactorial disease, including a number of causative and modifying factors, both endogenous and/or exogenous (Hanioka et al. 2011; Kalesinskas et al. 2014).

Among the factors related to the development of dental caries and other oral diseases, is the presence of dental biofilms. Biofilms are defined as microbial communities adhered to each other and covered with an extracellular polymeric matrix produced both by the microorganisms themselves and also by compounds derived from the host (Bjarnsholt et al. 2013). In the case of cariogenic biofilms, these still have high acidogenic ability, which is responsible for the decrease in local $\mathrm{pH}$ and demineralization of tooth tissue (Bowen and Koo 2011).
One of the main microorganisms responsible for initiating the demineralization process and consolidation of the acidic $\mathrm{pH}$ in the cariogenic biofilm is the Grampositive bacterium Streptococcus mutans. This bacterium is a natural colonizer of the oral cavity and was first identified by Clarke (1924). Currently, it is known that $S$. mutans, under favourable environmental conditions, can proliferate excessively in the oral cavity and use its diverse gene repertoire in the metabolism of carbohydrates for the production of acids that contribute locally to a $\mathrm{pH}$ drop (Salli et al. 2016).

Due to the high incidence of dental caries around the globe and because prevention is highly dependent on individual collaboration, new therapies have been researched to control the pathogenic oral microflora and thus reduce the incidence of such lesions (Walsh et al. 2015). One of the therapies that has received great visibility in the last year aims to use small molecules with high antibacterial activity and low cytotoxic activity, the antimicrobial peptides (AMPs) (Silva et al. 2012; Kreling et al. 2016). AMPs are a heterogeneous group of molecules produced 
by a wide range of tissues and cells in many invertebrates, plants and animals, usually acting on the innate defence system due to their antimicrobial characteristics against a wide variety of microorganisms (Batoni et al. 2011; Tao et al. 2011).

The antimicrobial peptide KR-12 is considered the lowest natural active peptide known, corresponding to amino acids 18-29 of the human cathelicidin peptide LL-37 (Wang 2008). Due to its small size, low toxicity and high solubility in culture media, this peptide has earned great attention and acted as a template in the design of new synthetic antimicrobial molecules (Mishra et al. 2013).

Therefore, this study aimed to describe the design and synthesis of a novel synthetic peptide based on the primary structure of KR-12 and the evaluation of its antimicrobial and anti-biofilm activities against three strains of S. mutans.

\section{Materials and methods}

\section{Bacterial strains and culture conditions}

Cariogenic strains Streptococcus mutans ATCC 25175, S. mutans (UA 159) ATCC 700610, and S. mutans (UA 130) ATCC 700611 were grown on brain heart infusion agar (BHIA, Difco, Himedia, Mumbai, India) for $24 \mathrm{~h}$ at $37^{\circ} \mathrm{C}$ and $5 \% \mathrm{CO}_{2}$. After growth on solid medium, isolated colonies were removed and inoculated into $5 \mathrm{ml}$ of fresh BHI broth and grown under the same conditions. Immediately before use, the bacterial suspension was adjusted to $10^{6}$ colony-forming units (CFU) $\mathrm{ml}^{-1}$ in BHI and used in the assays. Regarding assays involving biofilm formation, bacterial suspensions were adjusted in BHI supplemented with $1 \%$ sucrose (BHIs).

\section{Peptide synthesis, purification and preparation}

The peptides KR-12 (KRIVQRIKDFLR) and [W $\left.{ }^{7}\right]$ KR12KAEK (KRIVQRWKDFLRKAEK- $\mathrm{NH}_{2}$ ) were synthesized using a Protein PS-3 synthesizer by solid phase peptide synthesis (Merrifield 1963) using standard 9-fluorenylmethyloxycarbonyl (Fmoc) protocols on Fmoc-Arg(Pbf). The amino acids were coupled at a fourfold excess using O-benzotriazole-N, $\mathrm{N}, \mathrm{N}^{\prime}, \mathrm{N}^{\prime}$-tetramethyluroniumhexafluoro-phosphate (HBTU)/N-methylmorpholine (NMM) ( $\left.\mathrm{v} \mathrm{v}^{-1}\right)$ with $\mathrm{N}, \mathrm{N}$-dimethylformamide (DMF). The $a$-amino group deprotection step was performed in 20\% 4-methylpiperidine/DMF for 1 and $20 \mathrm{~min}$. Cleavage of the peptides from the resin and removal of the side chain protecting groups were simultaneously performed with 95\% trifluoroacetic acid (TFA), 2.5\% water, and 2.5\% triisopropyl silane for $2 \mathrm{~h}$. After this procedure, the crude peptides were precipitated with anhydrous ethyl ether, separated from soluble non-peptide material by centrifugation, extracted into 5\% solvent B $\left(0.036 \%\left(\mathrm{v} \mathrm{v}^{-1}\right)\right.$ TFA/acetonitrile) and $95 \%$ solvent $\mathrm{A}\left(0.045 \%\left(\mathrm{v} \mathrm{v}^{-1}\right) \mathrm{TFA} /\right.$ $\mathrm{H}_{2} \mathrm{O}$ ) and lyophilized. The crude peptides were purified by semi-preparative HPLC on a Beckman System Gold using a reversed-phase C18 column with a linear gradient of 5-45\% solvent B for $90 \mathrm{~min}$. The flow rate was $5 \mathrm{ml} \mathrm{min}{ }^{-1}$. Ultraviolet (UV) detection was carried out at $220 \mathrm{~nm}$. The peptide homogeneity was then checked by analytical HPLC on a Shimadzu system, using solvents A and $B$ with a linear gradient of 5-95\% $\left(\mathrm{v} \mathrm{v}^{-1}\right)$ solvent $\mathrm{B}$ for

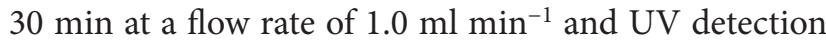
at $220 \mathrm{~nm}$. The identity of the peptide was confirmed by mass spectrometry in positive-ion mode ESI on a Bruker model apparatus.

The peptides were fully solubilized in sterile deionized water with $0.1 \%$ acetic acid $\left(\mathrm{CH}_{3} \mathrm{COOH}\right)$ at a concentration of $500 \mu \mathrm{g} \mathrm{ml}^{-1}$ prior to use and stored in a freezer at $-20^{\circ} \mathrm{C}$.

\section{Circular dichroism spectra}

The circular dichroism spectra were obtained between 190 and $250 \mathrm{~nm}$ using a JASCO J-815 CD spectrophotometer (Tokyo, Japan) on nitrogen flush in $1 \mathrm{~mm}$ path length quartz cuvettes at room temperature. The peptide concentration was $85 \mu \mathrm{mol} \mathrm{l}{ }^{-1}$. To investigate the conformational changes in membrane environments, a solution containing $10 \mathrm{mmoll}^{-1}$ of lysophosphatidylcholine (LPC) was used. The $\mathrm{CD}$ spectra were recorded as an average of six scans obtained in millidegrees and converted to molar ellipticity $[\theta]$ (in $\operatorname{deg} \mathrm{cm}^{2} \mathrm{dmol}^{-1}$ ). The curves were smoothed to eliminate instrument noise.

\section{Minimum inhibitory concentration (MIC) and minimum bactericidal concentration (MBC) determination}

The antimicrobial activity of both peptides was assessed by the microdilution method in 96-well polystyrene 'U'-bottom plates. The wells were filled with BHI containing the peptide at concentrations ranging from 500 to $7.8 \mu \mathrm{g} \mathrm{ml}^{-1}$ to a final volume of $100 \mu \mathrm{l}$. Afterwards, $100 \mu \mathrm{l}$ of bacterial suspensions at $2 \times 10^{6} \mathrm{CFU} \mathrm{ml}^{-1}$ were added to the wells. Chlorhexidine gluconate $(0.12 \%)$ and $\mathrm{BHI}$ medium were used as positive and negative controls, respectively. The plates were then incubated at $37^{\circ} \mathrm{C}$ with $5 \% \mathrm{CO}_{2}$ for $24 \mathrm{~h}$. After incubation, the absorbance of each well at $620 \mathrm{~nm}$ was determined by using a microplate reader (SpectraMax ${ }^{\circledR}$ I3, Molecular Devices, Sunnyvale, CA, USA). The MIC was defined as the lowest concentration of peptide capable of inhibiting visible bacterial growth. 
To determine the MBC, Petri dishes containing BHIA were inoculated with $10 \mu \mathrm{l}$ of the content of wells that showed no visible growth. The $\mathrm{MBC}$ was defined as the lowest concentration of peptide capable of completely inhibiting bacterial growth on BHIA.

\section{Effect of KR-12 and [W']KR12-KAEK on biofilm formation}

The effects of peptides on biofilm formation were determined through assays performed in 96-well polystyrene 'flat' bottom plates according to Stepanovic et al. (2000), with modifications. Briefly, the plates were prepared as previously described for MIC determination. Two plates for each peptide were prepared, one for quantification of biomass using crystal violet and the other for enumeration of biofilm-entrapped cells. The number of cells was

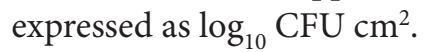

\section{Quantification of biomass}

After growth for $24 \mathrm{~h}$ at $37^{\circ} \mathrm{C}$, the plates were washed three times with sterile distilled water, and then $200 \mu$ lof $99.8 \%$ methanol were added for $15 \mathrm{~min}$ to fix adhered cells. After methanol removal, $200 \mu \mathrm{l}$ of $1 \%$ crystal violet were added to each well and interacted with the biomass for 5 $\mathrm{min}$. The plates were then washed and dried at room temperature. To dissolve the dye bound to the biofilm mass, $200 \mu \mathrm{l}$ of $33 \%$ acetic acid were added to the wells, and the absorbance was measured at $595 \mathrm{~nm}$ with a microplate reader (SpectraMax ${ }^{\oplus}$ I3, Molecular Devices) (Stepanovic et al. 2000).

\section{Enumeration of biofilm-entrapped cells}

After incubation for $24 \mathrm{~h}$ at $37^{\circ} \mathrm{C}$, the plates were washed three times with sterile distilled water to remove weakly adhered cells. Then, $200 \mu \mathrm{l}$ of sterile $0.9 \% \mathrm{NaCl}$ were added to each well, and the plates were subjected to an ultrasonic bath (Sonicor/SC-52) for 6 min to release biofilm-entrapped cells. The volume of five wells was collected into a sterile $2 \mathrm{ml}$ microtube to a final volume of $1 \mathrm{ml}$. Tenfold serial dilutions were performed for subsequent plating. After plating, the plates were incubated at $37^{\circ} \mathrm{C}$ with $5 \%$ $\mathrm{CO}_{2}$ for $24 \mathrm{~h}$ (Machado et al. 2012). The number of CFU

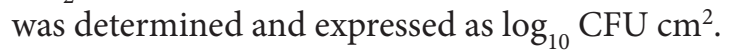

\section{Effect on preformed biofilms}

To evaluate the activity of peptides on preformed biofilms, the wells were filled with $200 \mu \mathrm{l}$ of a bacterial suspension at $10^{6}$ cells ml ${ }^{-1}$ and incubated for $24 \mathrm{~h}$ at $37^{\circ} \mathrm{C}$ with $5 \% \mathrm{CO}_{2}$. Afterwards, the supernatant was discarded, and the wells were washed twice with $200 \mu$ l of sterile distilled water for removal of non-adherent cells. Then, $200 \mu \mathrm{l}$ of peptides at concentrations ranging from 7.8 to
$500 \mu \mathrm{g} \mathrm{ml}^{-1}$ and solubilized in BHI were added to the wells. Chlorhexidine gluconate at $0.12 \%$ and $\mathrm{BHI}$ were added to separate wells as positive and negative controls, respectively. The plates were then incubated for $24 \mathrm{~h}$ at $37^{\circ} \mathrm{C}$ in $5 \% \mathrm{CO}_{2}$. After $24 \mathrm{~h}$, the medium was removed, and each well was washed twice with $200 \mu \mathrm{l}$ of sterile saline solution (150 mM sodium chloride). The effect of peptide on preformed biofilms was evaluated by biomass quantification and enumeration of biofilm-entrapped cells as previously described.

\section{Scanning electron microscopy}

The plates were filled and incubated as described for the biofilm growth inhibition test and for preformed biofilms. For the first situation, $\left[\mathrm{W}^{7}\right] \mathrm{KR} 12$-KAEK at $15.6 \mu \mathrm{g} \mathrm{ml}{ }^{-1}$ was tested with $S$. mutans UA130. For evaluating preformed biofilms, $\left[\mathrm{W}^{7}\right]$ KR12-KAEK at $500 \mu \mathrm{g} \mathrm{ml}{ }^{-1}$ was used.

The plates were removed from incubation, and cells weakly adhered were removed by washing with sterile ultrapure water, and the plates were then allowed to dry at room temperature. Wells containing biofilms were dehydrated sequentially with increasing concentrations of ethanol (70\% for $10 \mathrm{~min}, 95 \%$ for $10 \mathrm{~min}$ and $100 \%$ for $20 \mathrm{~min}$ ) and allowed to dry at room temperature. After drying, they were kept in a desiccator until analysis. Before observation, cells were placed on aluminium holders and covered with gold particles and then observed under a scanning electron microscope (Quanta 450 FEG, FEI, Waltham, MA, USA).

\section{Statistical analysis}

All experiments were performed in triplicate, and the results were entered into Microsoft Excel (Version 2010 for Windows) and later analysed with GraphPad Prism software (version 5.0 for Windows). To determine the significant differences between groups, a one-way ANOVA was performed with a Bonferroni post-test, and $p<0.05$ was considered significant.

\section{Results}

\section{Peptide synthesis}

Based on KR12, a new analogue peptide called $\left[\mathrm{W}^{7}\right] \mathrm{KR} 12$ KAEK was designed. The peptide contains a Trp instead of Ile residue in position 7. It has been proposed that the presence of tryptophan increases the affinity of antimicrobial peptides for biological membranes (Wimley and White 1996; Chan et al. 2006). The addition of Trp in hylin-a1 increases the activity against bacteria and fungi 
(Crusca et al. 2011). In addition, Trp could be used as a probe to analyse the interaction with membranes through modification of fluorescence. It has been described in the literature that positive charge, helicity, hydrophobicity and amphipathic characteristics are correlated with increased activity of antimicrobial peptides (Chen et al. 2005; Cespedes et al. 2012). Therefore, the sequence KAEK was added at the C-terminus of KR12. The two lysines increase the positive charge. The peptide KR12 has a charge of +5 at physiological $\mathrm{pH}$ and the analogue has +6 . The main differences in the physico-chemical properties of KR12 and the analogue are shown in Table 1 . The specific position of these four amino acids increases the amphipathicity of the new peptide. The Schiffer-Edmundson helical wheel diagram (Figure 1) of KR12 and [ $\left.\mathrm{W}^{7}\right] \mathrm{KR} 12$-KAEK reveals that the peptide has an amphipathic alpha-helix conformation with hydrophilic and hydrophobic residues on opposite sides forming an amphipathic conformation. This structure was increased by the modifications in the analogue peptide.

To confirm the amphipathic alpha-helical structure of $\left[\mathrm{W}^{7}\right] \mathrm{KR} 12-\mathrm{KAEK}$, the secondary structures were obtained by CD in PBS and LPC. The results presented in Figure 2A show that $\left[\mathrm{W}^{7}\right] \mathrm{KR} 12-\mathrm{KAEK}$ has a random coil structure in buffer solution. On the other hand, in the presence of

Table 1. Physico-chemical properties of KR12 and [W $\left.{ }^{7}\right] \mathrm{KR} 12-$ KAEK.

\begin{tabular}{lcc}
\hline Peptide/property & KR12 & [W7]KR12-KAEK \\
\hline Net charge & +5 & +6 \\
Charge density & 2.4 & 2.6 \\
Hydrophobicity* & 11.8 & 12.0 \\
\% Hydrophobic residues & 41.2 & 37.5 \\
Hydrophobic moment vectors** $^{*}$ & 45.2 & 53.3 \\
\hline
\end{tabular}

${ }^{*}$ RP-HPLC retention time.;

${ }^{* *}$ Angle between $\mathrm{HM}$ vector and z-axis.

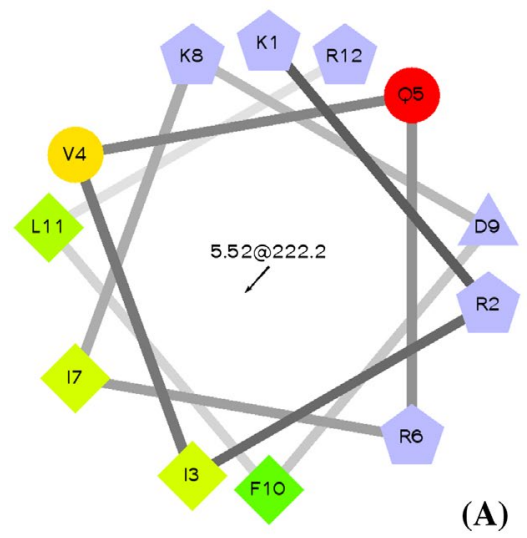

LPC, the peptide acquired a well-defined helical structure, with double minima at 207 and $222 \mathrm{~nm}$ and a maximum at $\sim 195 \mathrm{~nm}$. These results were similar to those obtained in a previous study for KR-12 (Mishra et al. 2013). In the present study, KR-12 did not form a helical structure in PBS buffer but became helical in the presence of lipid, with double minima at 207 and $222 \mathrm{~nm}$ and a maximum at $\sim 195 \mathrm{~nm}$. However, it is important to note that in PBS KR12 showed minima at $\sim 222 \mathrm{~nm}$, which indicates the presence of a small quantity of helical structure (Figure 2B). This was not observed in the analogue peptide. This observation shows that $\left[\mathrm{W}^{7}\right] \mathrm{KR} 12$-KAEK probably has a lower tendency to self-associate in solution. The helical content in solution under physiological conditions has been described as an important feature for biological activity (Ulaeto et al. 2016).

Another important parameter for the biological activity of antimicrobial peptides is the length of the sequence (Bahar and Ren 2013). The shortened melittin with 15 residues is less toxic than the original form (Subbalakshmi et al. 1999). Membrane pore-forming peptides need to match the membrane bilayer thickness to form stable pore structures (Ambroggio et al. 2005).

The addition of KAEK to KR-12 increases the number of residues from 12 to 16 . The number of amino acids forming the helical structure of KR-12 is not enough to pass through the membrane. The addition of four residues (one potential turn of alpha-helix) could allow the peptide to match the membrane thickness and is more favourable to form pores through association with peptide chains. The authors suggest that although shorter sequence peptides, such as KR12, are able to interact with the membrane bilayer, there is a mismatch between the peptide length and the bilayer thickness, which leads to a decreased activity compared to [W7]KR12-KAEK. Taken together, the physico-chemical parameters of length,

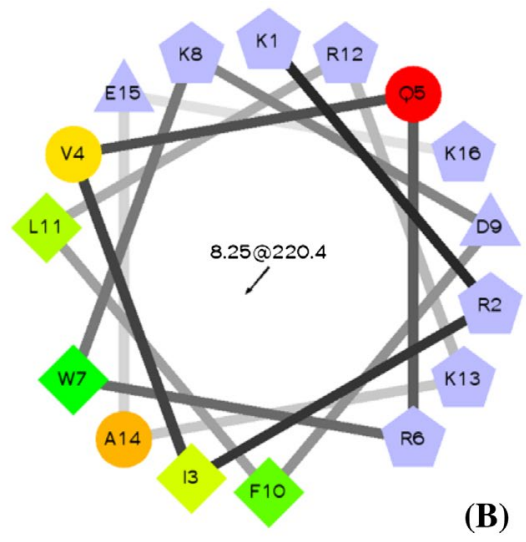

Figure 1. Schiffer-Edmundson helical wheel diagram demonstrating the probable amphipathic a-helical conformation of KR12 (A) and [W7]KR12-KAEK (B). Hydrophilic residues are represented as circles, hydrophobic residues as diamonds, potential negative charges as triangles, and potential positive charges as pentagons. (http://rzlab.ucr.edu/scripts/wheel/wheel. cgi?sequence $=$ ABCDEFGHIJLKMNOP\&submit=Submit). 

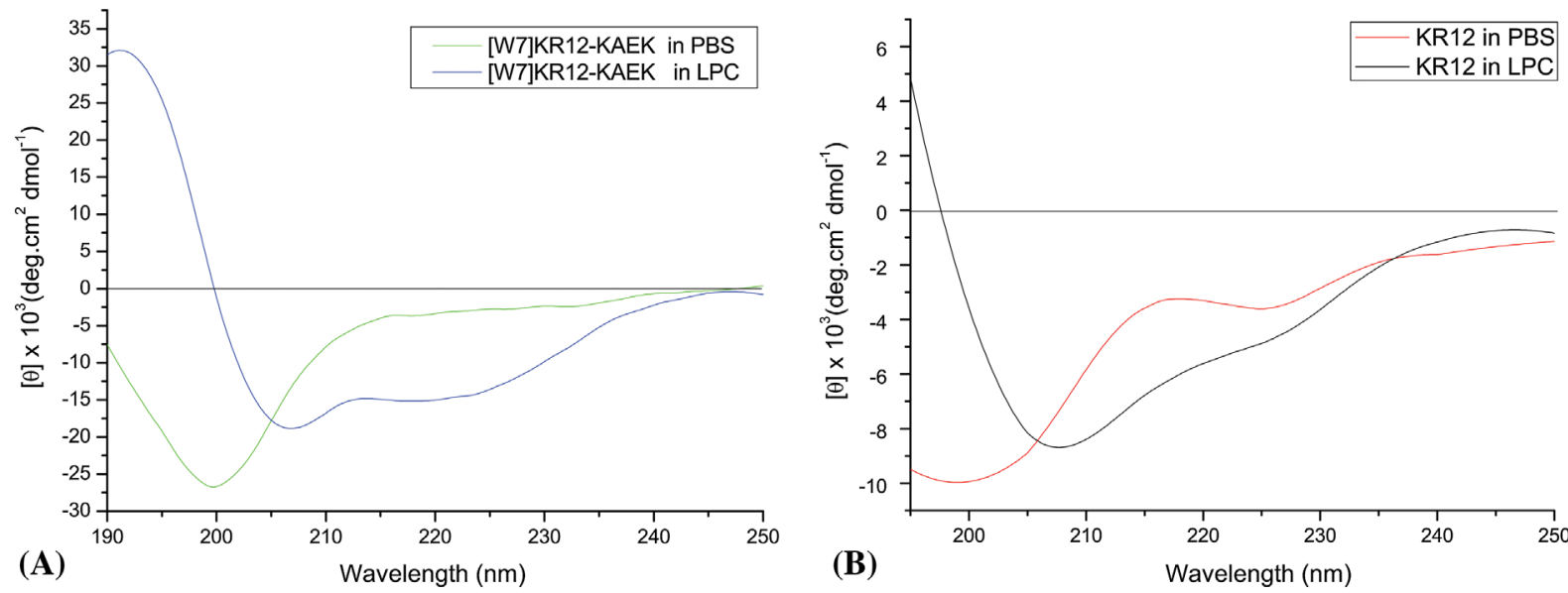

Figure 2. CD spectra of [W7]KR12-KAEK (A) and KR12 (B) in PBS (pH: 7.2) and LPC (10 mmol I-1) micelles. The peptide concentration was $30 \mu \mathrm{mol} \mathrm{I}^{-1}$.

Table 2. In vitro susceptibility of the oral microorganisms tested against the peptide KR12 and its analogue [W $\left.{ }^{7}\right]$ KR12-KAEK.

\begin{tabular}{lcccc}
\hline Microorganism & Strain & $\begin{array}{c}\text { MIC values KR12 peptide } \\
\left(\mu \mathrm{g} \mathrm{ml}^{-1}\right)\end{array}$ & $\begin{array}{c}\text { MBC values KR12 } \\
\left.\text { peptide }(\mu \mathrm{g} \mathrm{m})^{-1}\right)\end{array}$ & $\begin{array}{c}\text { MIC values } \\
{\left[W^{7}\right] K R 12-K A E K\left(\mu g \mathrm{ml}^{-1}\right)}\end{array}$ \\
\hline Streptococcus mutans & ATCC 25175 & - & - & 31.25 \\
Streptococcus mutans & UA 159 & - & - & 31.25 \\
Streptococcus mutans & UA 130 & - & - & 31.25 \\
\hline
\end{tabular}

charge, hydrophobicity and structure certainly affect the biological activity of peptides.

\section{Antimicrobial activity}

Concerning the assays to evaluate antimicrobial potential, both peptides showed considerably different activities on the strains tested (Table 2). Whereas KR12 had no significant antimicrobial activity, the peptide $\left[\mathrm{W}^{7}\right] K R 12$-KAEK demonstrated bacteriostatic and bactericidal effects, with $\mathrm{MIC}$ and $\mathrm{MBC}$ values ranging from 7.8 to $31.25 \mu \mathrm{g} \mathrm{ml}{ }^{-1}$ and 15.6 to $62.5 \mu \mathrm{g} \mathrm{ml}^{-1}$, respectively.

\section{Effects on biofilm formation}

\section{Biomass quantification}

Treatment with KR12 did not result in significant alterations in biofilm formation by S. mutans (Figure 3A-C). The exception was the UA130 strain treated with KR12 at $250 \mu \mathrm{g} \mathrm{ml}^{-1}$, which had its biomass reduced by $20 \%$ when compared to the negative control (Figure 3A).

On the other hand, the peptide $\left[\mathrm{W}^{7}\right]$ KR12-KAEK inhibited the production of biomass by all strains at most of the concentrations tested (Figure 3D-F). In comparison to the negative control, significant differences $(p<0.001)$ were achieved. Strain UA130 was slightly more susceptible to $\left[\mathrm{W}^{7}\right]$ KR12-KAEK, since all concentrations were able to inhibit its biomass production. Furthermore, treatment with concentrations $>31.25 \mu \mathrm{g} \mathrm{ml} \mathrm{g}^{-1}$ resulted in reductions in biomass production of $\sim 96-100 \%$ by both $S$. mutans UA130 and UA159 strains (Figure 3D and E).

When compared to the other strains, S. mutans ATCC25175 was slightly less susceptible to $\left[\mathrm{W}^{7}\right]$ KR12KAEK. Treatment with the peptide at concentrations ranging from 15.6 to $31.25 \mu \mathrm{g} \mathrm{ml}^{-1}$ caused significant interference in biofilm formation, with biomass reduction ranging from 48 to $74 \%$. Concentrations above $62.5 \mu \mathrm{g} \mathrm{ml}^{-1}$ reduced biomass production from 99 to $100 \%$. Compared to the negative control, biomass production was increased by treatment with $7.8 \mu \mathrm{g} \mathrm{ml}^{-1}$ of the peptide $(p<0.001)$ (Figure 3F).

\section{Enumeration of biofilm cells}

The assays were carried out with each peptide at different concentrations (Figure 4A-F). However, $\left[\mathrm{W}^{7}\right]$ KR12KAEK was tested only at concentrations below the MBC, as no colony forming unit (CFU) was found in groups treated with concentrations $>62.5 \mu \mathrm{g} \mathrm{ml}^{-1}$ (Figure 4D-F).

Similar to the effects found in assays for biomass production, KR12 at $250 \mu \mathrm{g} \mathrm{ml}^{-1}$ showed activity only on S. mutans UA130, which had its viability significantly reduced.

On the other hand, $\left[\mathrm{W}^{7}\right]$ KR12-KAEK showed a dose-dependent activity against all evaluated strains. $S$. mutans UA130 was highly susceptible to the peptide. Despite the discrete effect on biomass formation, the 
Streptococcus mutans UA 130

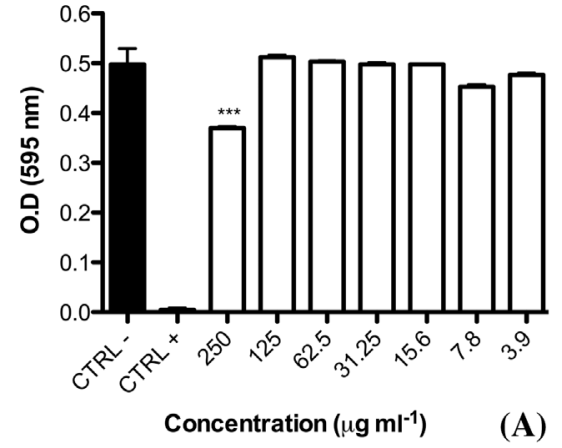

Streptococcus mutans UA 130

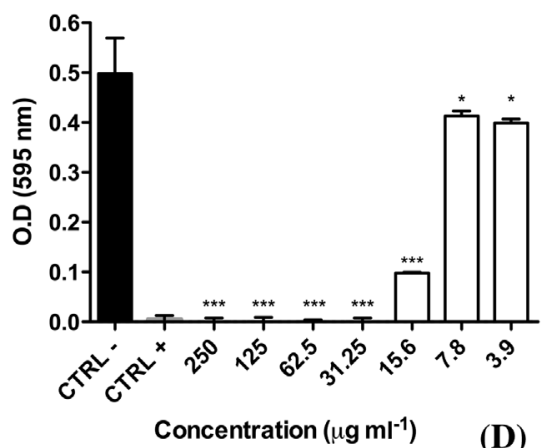

(D)
Streptococcus mutans UA 159

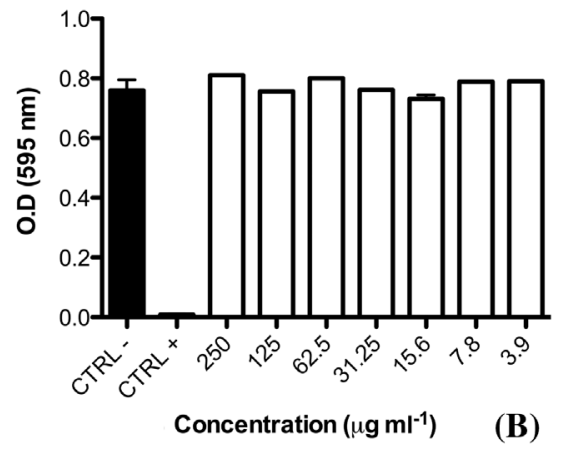

Streptococcus mutans UA 159

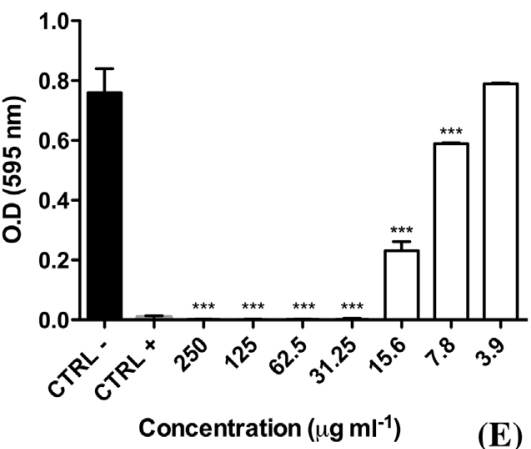

Streptococcus mutans ATCC25175

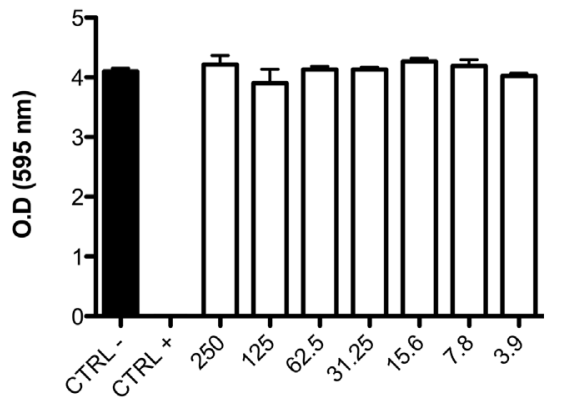

Concentration $\left(\mu \mathrm{g} \mathrm{ml}^{-1}\right)$

(C)

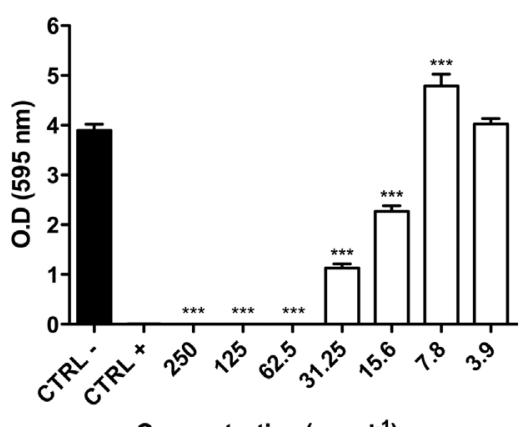

(F)

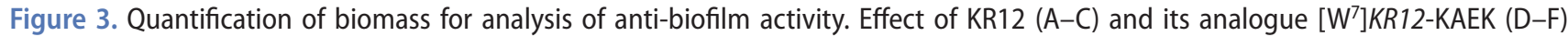
against the S. mutans strains analysed. Peptide tested (White), negative control (Black) and chlorhexidine gluconate $0.12 \%$ (Gray). ${ }^{*} p<0.05$; ${ }^{* * *} p<0.001$.

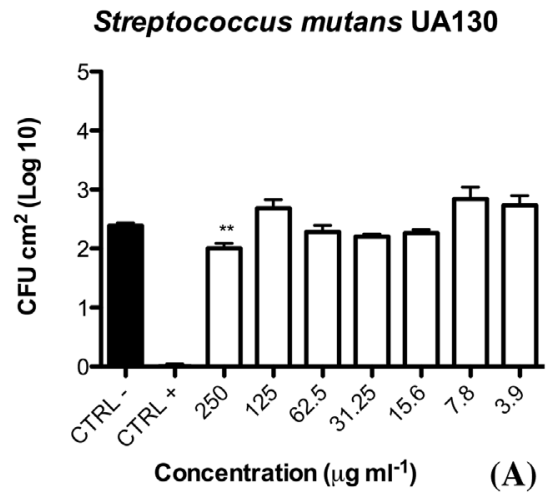

Streptococcus mutans UA 130

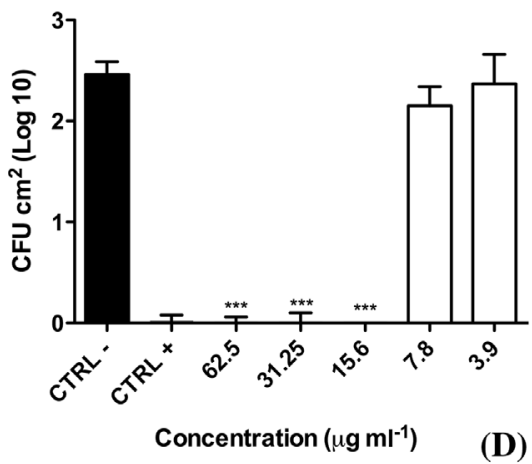

Streptococcus mutans UA 159

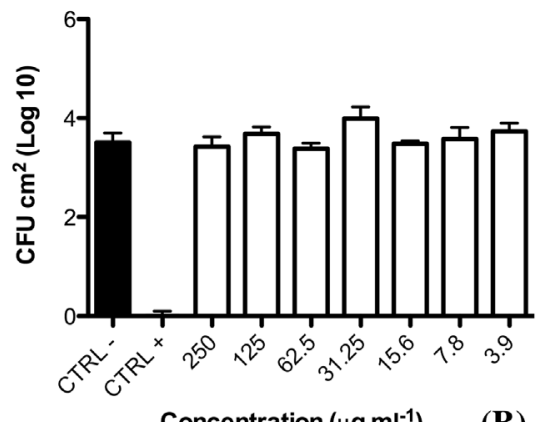

(B)

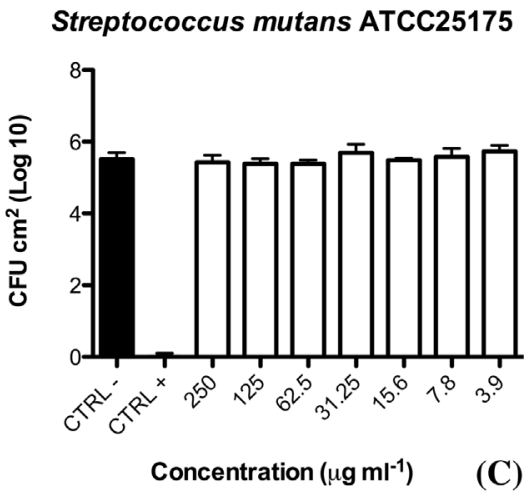

Streptococcus mutans ATCC25175

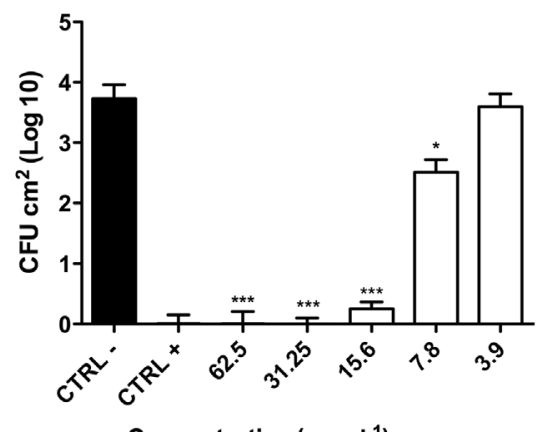

(E)

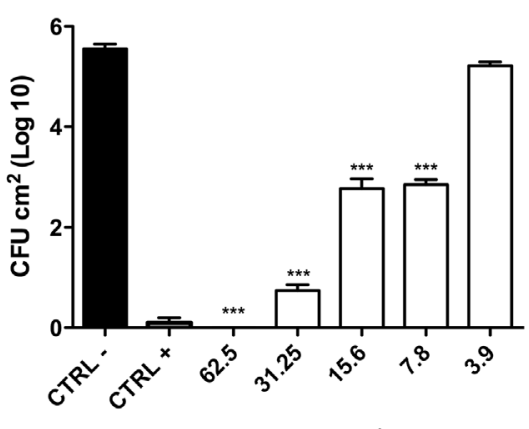

Concentration $\left(\mu \mathrm{g} \mathrm{ml}^{-1}\right)$
(F)

Figure 4. Counting of CFUs for analysis of anti-biofilm activity. Effect of KR12 (A-C) and its analogue [W] KR12-KAEK (D-F) against the $S$. mutans strains analysed. Peptide tested (White), negative control (Black) and chlorhexidine gluconate $0.12 \%$ (Gray). ${ }^{*} p<0.05 ;{ }^{* *} p<0.01$; ${ }^{* * *} p<0.001$. 
peptide decreased UA130 viability even at the lowest concentrations evaluated (Figure 4D). Regarding the strain UA159, the results were consistent with the reduction in biomass previously reported in this study. Indeed, the reduction in viability reached values as high as $82 \%$ at a concentration of $15.6 \mu \mathrm{g} \mathrm{ml}^{-1}$ (Figure $4 \mathrm{E}$ ).

Although S. mutans ATCC25175 had the lowest susceptibility to $\left[\mathrm{W}^{7}\right] K R 12$-KAEK, the peptide decreased the viability of cells growing in biofilms. The effect was seen mainly at peptide concentrations of 15.6 and $31.25 \mu \mathrm{g} \mathrm{ml}^{-1}$, reaching reductions of $\sim 41 \%$ and $67 \%$, respectively. In addition, an interesting result was found on biofilms treated with a peptide concentration of $7.8 \mu \mathrm{g} \mathrm{ml}^{-1}$. Even with a high quantity of biomass, as demonstrated by the previous assay, the viability was reduced by $\sim 40 \%$ (Figure $4 \mathrm{~F})$.

\section{Activity of peptides on preformed biofilms}

The assays were performed with both peptides, and the results are presented in Figures 5 and 6. No effect of KR12 was found. S. mutans UA130 had its biomass increased by treatment with the peptide at concentrations of 250 and $31.25 \mu \mathrm{g} \mathrm{ml}^{-1}$ but without any change in cell viability (Figure 5A and D). Regarding S. mutans UA159, a slight decrease in biomass was seen at the highest peptide concentration but without any reduction in cell viability (Figure 5B and $\mathrm{E}$ ).

Regarding the effect of $\left[\mathrm{W}^{7}\right]$ KR12-KAEK on the biomass of preformed biofilms, only a small amount of activity was achieved $(p<0.001)$ in the case of $S$. mutans UA159. Moreover, the best result was obtained when the highest peptide concentration was used (Figure 6B). On the other hand, $\left[\mathrm{W}^{7}\right]$ KR12-KAEK decreased the cell viability of biofilms from all strains evaluated. The effect on $S$. mutans UA130 was seen in concentrations ranging from $62.5 \mu \mathrm{g} \mathrm{ml}^{-1}$ to $500 \mu \mathrm{g} \mathrm{ml}^{-1}$. When the highest concentration was used, the peptide performed better than the positive control $(p<0.001)$ (Figure 6D). Significant activity was also seen on $S$. mutans UA159 and $S$. mutans ATCC25175. However, the effect on both strains was mainly restricted to the highest concentration of the peptide (Figure 6E and F).

\section{Scanning electron microscopy}

In Figure 7A and B, the biofilm of S. mutans UA159 formed in the presence of the negative control. The classical chains of diplococcus can be observed. On the other hand, Figure $7 \mathrm{C}$ and D shows the biofilm of $S$. mutans UA130 in the presence of $\left[\mathrm{W}^{7}\right]$ KR12-KAEK at a concentration of $15.6 \mu \mathrm{g} \mathrm{ml}^{-1}$. Furthermore, the biofilm in the
Streptococcus mutans UA130

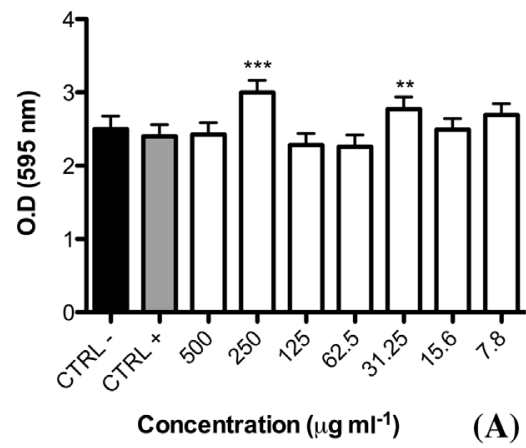

Streptococcus mutans UA130

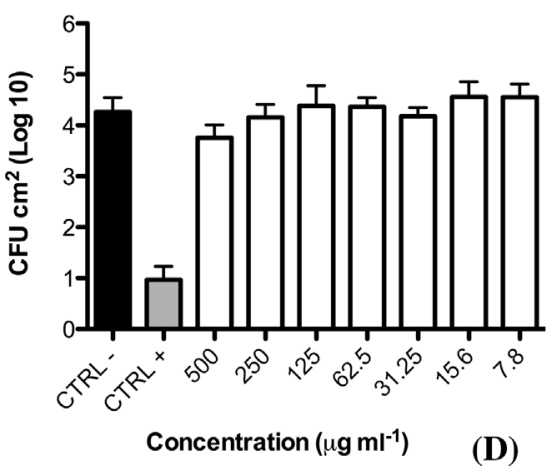

Streptococcus mutans UA159

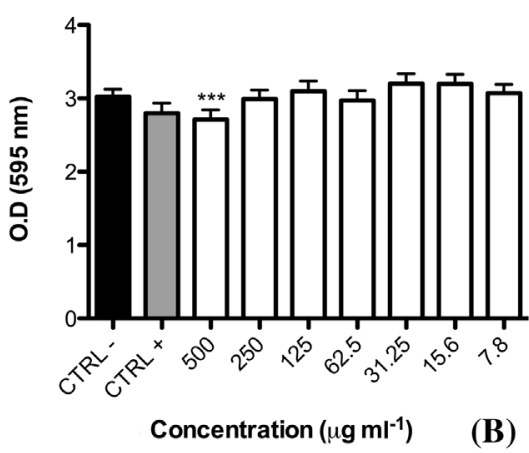

Streptococcus mutans UA159

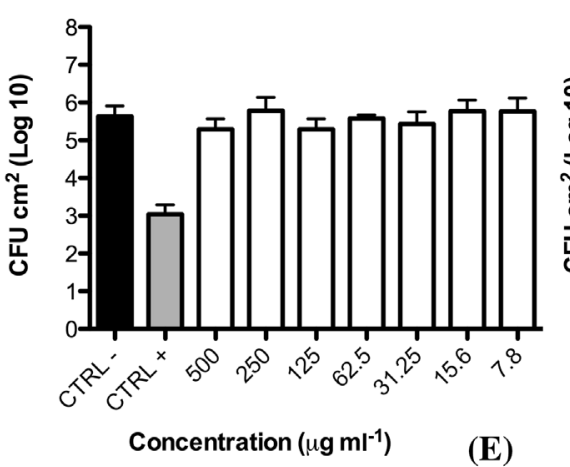

Streptococcus mutans ATCC25175

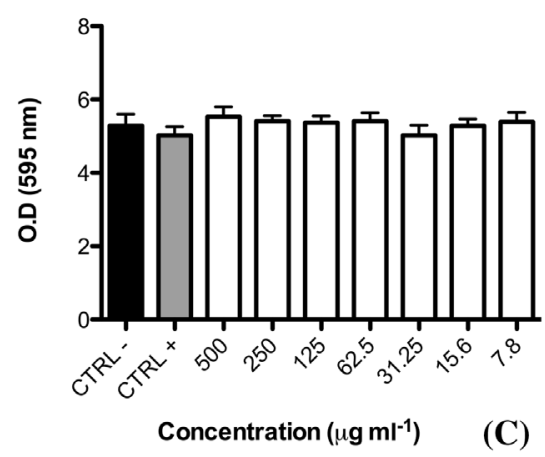

Streptococcus mutans ATCC25175

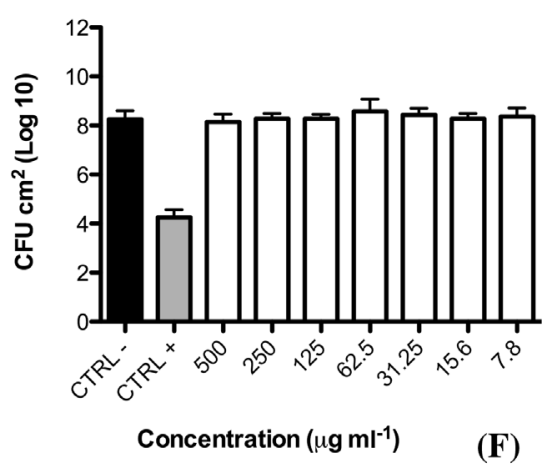

Figure 5. Anti-biofilm activity of KR12 on preformed biofilms. Quantification of biomass (A-C) and counting of colony forming units (DF) of the S. mutans strains analysed. Peptide tested (White), negative control (Black) and chlorhexidine gluconate $0.12 \%$ (Gray). ${ }^{* *} p<0.01$; ${ }^{* * *} p<0.001$. 
Streptococcus mutans UA130

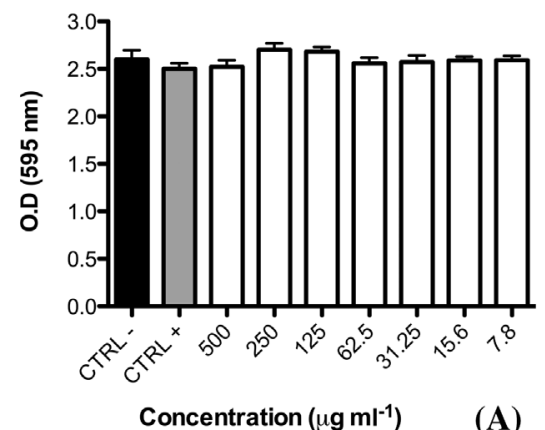

Streptococcus mutans UA130

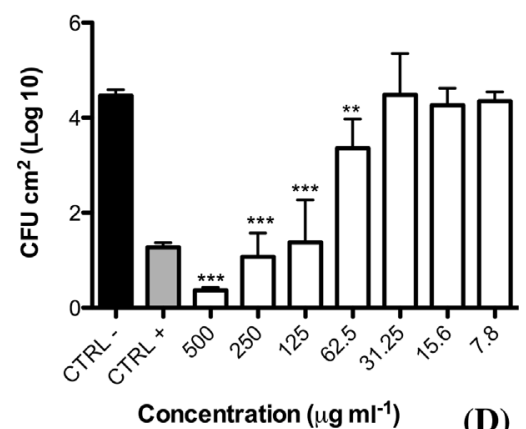

Concentration $\left(\mu \mathrm{g} \mathrm{ml}^{-1}\right)$
(A)

(D)

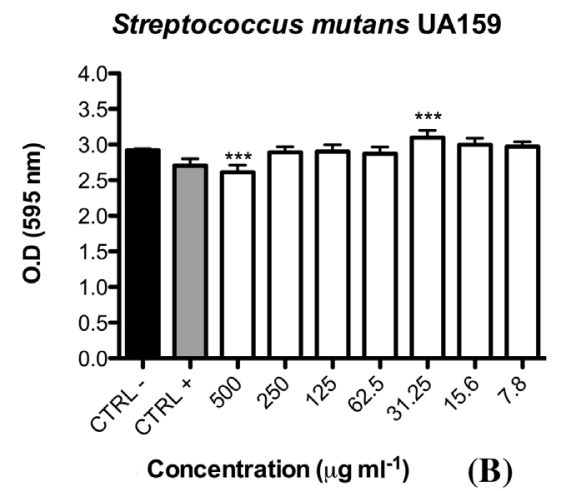

Streptococcus mutans UA159

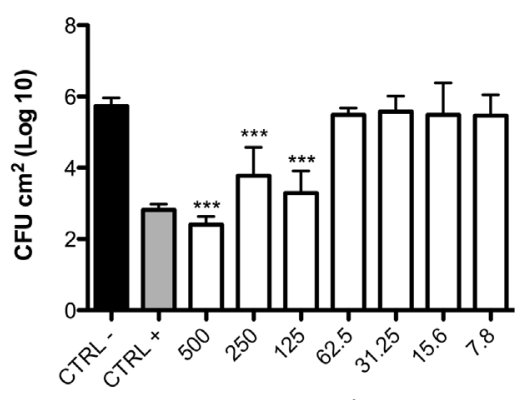

Concentration $\left(\mu \mathrm{g} \mathrm{ml}^{-1}\right)$

(E)
Streptococcus mutans ATCC25175

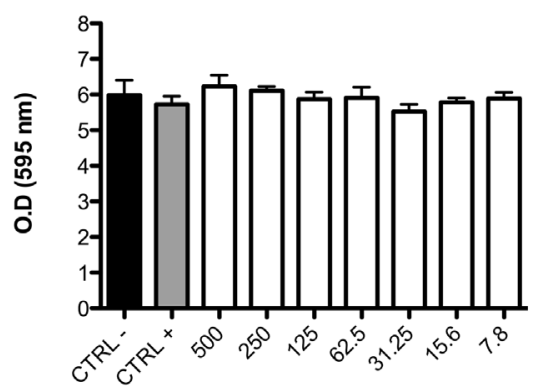

Concentration $\left(\mu \mathrm{g} \mathrm{ml}^{-1}\right)$

(C)

\section{Streptococcus mutans ATCC25175}

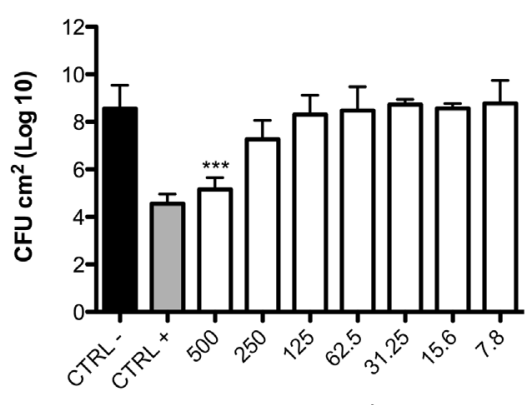

Concentration $\left(\mu \mathrm{g} \mathrm{ml}^{-1}\right)$

Figure 6. Anti-biofilm activity of [W7]KR12-KAEK on preformed biofilms. Quantification of biomass (A-C) and counting of CFUs (D-F) of the S. mutans strains analysed. Peptide tested (White), negative control (Black) and chlorhexidine gluconate $0.12 \%$ (Gray). ${ }^{* *} p<0.01$; ${ }^{* * *} p<0.001$.

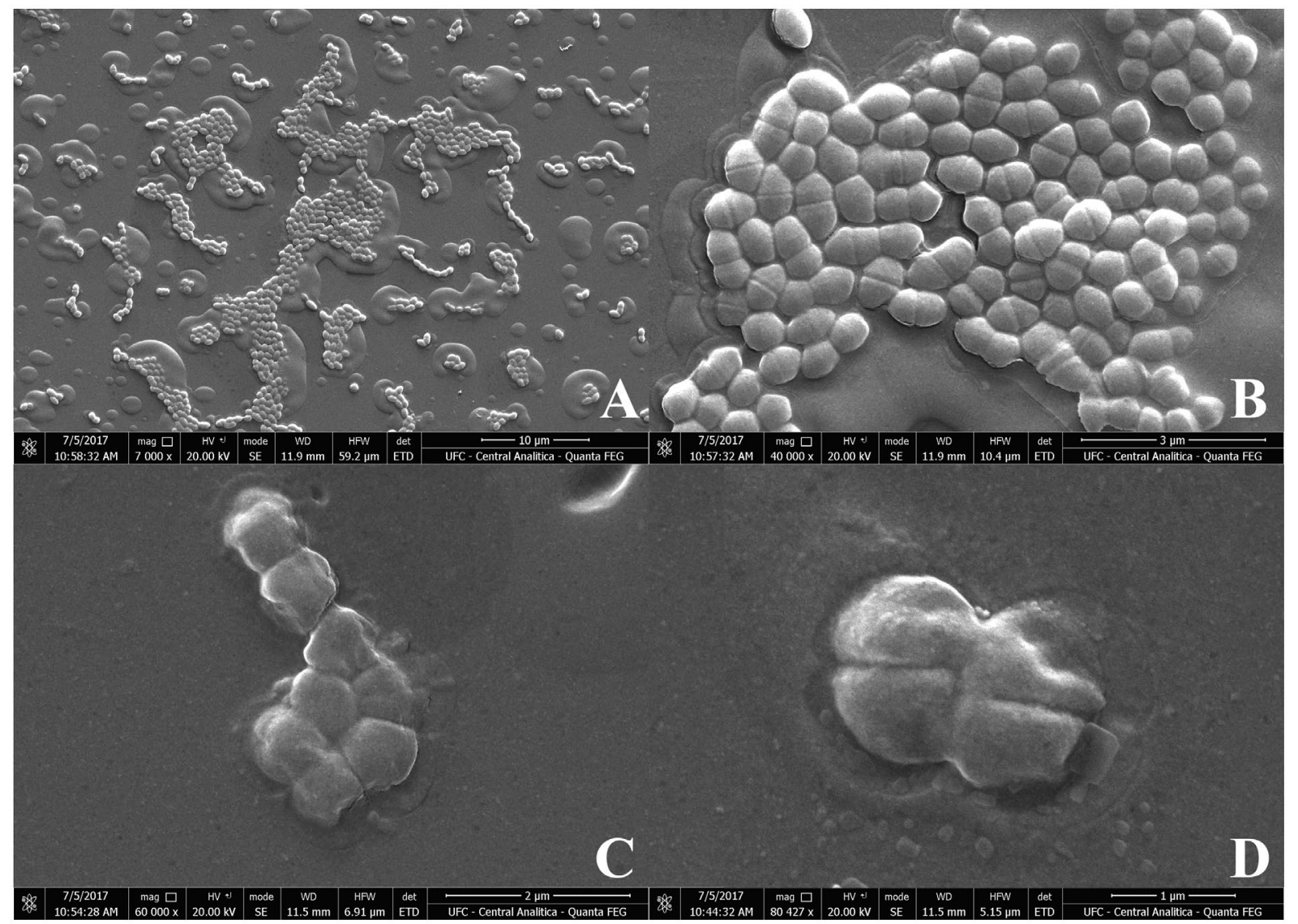

Figure 7. SEM images of 24-h biofilm formation by S. mutans UA130 incubated with the negative control (A and B) and with [W $\left.{ }^{7}\right] K R 12-$ KAEK at a concentration of $15.6 \mu \mathrm{g} \mathrm{ml}^{-1}$ (C and D). 


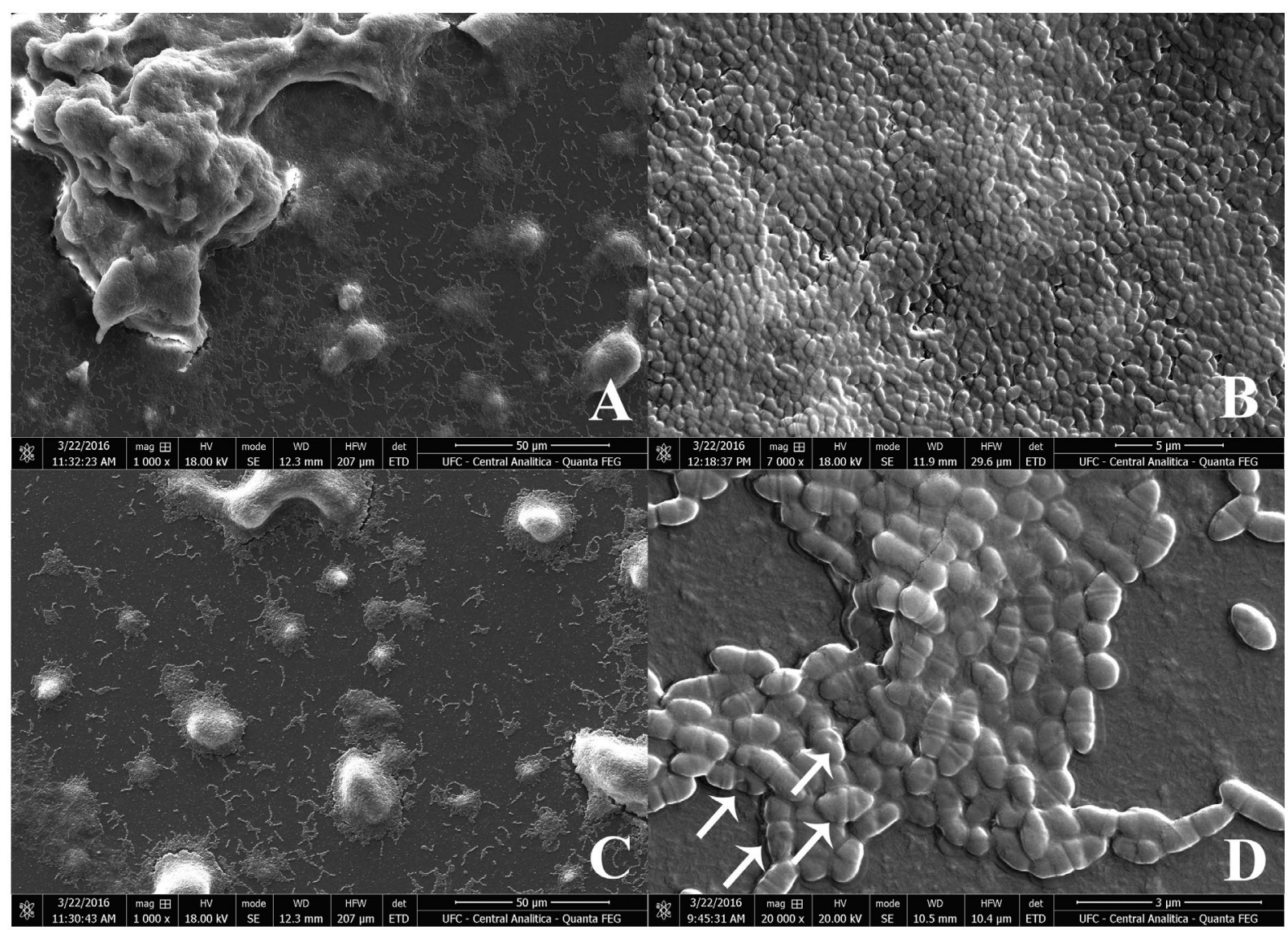

Figure 8. SEM images of a preformed biofilm of S. mutans UA130 incubated with the negative control (A and B) and with [W $]$ KR12-KAEK at a concentration of $500 \mathrm{\mu g} \mathrm{ml}^{-1}$ (C and D). White arrows indicate morphological changes in bacterial structure.

presence of peptide showed clear changes in the cellular structural conformation, suggesting the interaction of the peptide with the bacterial membrane.

Figure $8 \mathrm{~A}$ and $\mathrm{B}$ show intense biofilm formation by S. mutans UA130 after incubation with the negative control (BHI). High amounts of extracellular polymeric substances (EPS) can be observed. On the other hand, images of the same strain treated with the peptide showed smaller microcolony formation associated with lower deposition of matrix in preformed biofilms (Figure 8C and D). Moreover, some cells were seen with apparent morphological changes, suggesting membrane alterations caused by the peptide (Figure 8D).

\section{Discussion}

The great effectiveness of natural antimicrobial peptides (AMPs) justifies the research effort to elucidate their function and eventually turn them into new antimicrobial agents to fight microbial resistance to conventional antibiotics (Mishra et al. 2013). The participation and contributions of many laboratories around the world have led to a substantial increase in the number of such peptides. Until June 2016, there were 2,260 AMPs in the antimicrobial peptide database (APD); however, of these and to date, only 21 have scientifically proven anti-biofilm activity (http://aps.unmc.edu/AP/main.php). Meanwhile, synthetically modified peptides are produced - molecules with changes in their primary structure that allow an increase in their antimicrobial activity and reduce their potential cytotoxicity. The KR-12 peptide is a shortened antimicrobial peptide which has relative selectivity for Gram-negative bacteria (Wang 2008; Wang, Epand, et al. 2012). However, changes in native peptides can effectively increase their profile of action and antimicrobial potential.

The scientific literature shows that the native peptide KR-12 and its analogues or derivatives have never been tested against biofilms of oral bacteria. In this study, through the addition of certain amino acids at specific positions, a significant increase in the antimicrobial activity of the peptide was observed, increasing its spectrum of action to bacteria previously not susceptible to it. Trp is of particular interest due to its propensity to position itself near the membrane/water interface. In other studies, addition of Trp has promoted an increase in biological activity (Crusca et al. 2011). The sequence KAEK was added at the C-terminus position of KR-12, increasing the chain size of the peptide and its amphipathicity. This modification also 
increased the charge of the peptide. Studies have shown that the biological activity of antimicrobial peptides generally correlates with the propensity for helical formation, hydrophobicity, cationic properties and amphipathicity (Chen et al. 2005; Cespedes et al. 2012). These properties are directly related to the ability of the peptide to interact with the bacterial membrane and form pores that lead to cell lysis and death.

Among the main mechanisms suggested for the biocide activity of AMPs, there are models of extracellular cell death and models for intracellular cell death (Brogden 2005). Regarding the former, the AMPs are initially attracted to the surface of the microorganism by electrostatic interactions between the anionic or cationic peptide and structures on the cell surface. After the initial attraction, the AMP binds to the cell surface and initiates the connection phase stage that is responsible for performing the movement of the AMP across the outer membrane and allows the AMP to interact directly with the bacterial cytoplasmic membrane. At low peptide/lipid ratios, the AMPs are connected in parallel to the lipid bilayer. As this ratio increases, the peptides begin to orientate perpendicularly to the membrane. If the peptide/lipid ratios are high, the AMP starts its penetration into the cell membrane, which leads to the formation of transmembrane pores and subsequent cell death by loss of the cytoplasmic membrane by liquid breakage and micellization (Brogden 2005; Paulsen et al. 2013). This model of action helps to explain the morphological changes displayed by scanning electron microscopy.

While lysis of the cell membrane leads to bacterial death, an increasing number of studies have reported the existence of other methods of cell death. Research has revealed the presence of significant intracellular targets for cell death (Futaki et al. 2001; Richard et al. 2003; Wadia et al. 2004). Although the present authors have no evidence for this activity, the results show a reduction in the production of biomass by the evaluated microorganisms, which may suggest a possible intervention of the peptide tested in this metabolic pathway, as well as other molecules like mersacidin and pleurocidin described in the literature (Brötz et al. 1998; Patrzykat et al. 2002).

Because of the role of $S$. mutans in the dental demineralization process, several studies propose new methods of controlling microbial colonization. With respect to AMPs, several studies evaluated the antimicrobial potential of such molecules against strains of $S$. mutans (Wang, Tao, et al. 2012; da Silva et al. 2013; Zhang et al. 2016). However, few of these studies evaluated the anti-biofilm effect of AMPs, either by interfering in the formation of these communities or through their effect on preformed biofilms (da Silva et al. 2013). In this study, it was found that, under sub-inhibitory concentrations, there was an increase in the biomass, although a significant decrease in the number of colony forming units was found at the same concentrations. This was noticed both in the inhibitory biofilm assays and in the assays for preformed biofilms. This finding suggests that, under the stress of $\left[\mathrm{W}^{7}\right] K R 12$ KAEK, the remaining cells and, consequently, the more tolerant ones, increased the production of EPS as a defence mechanism against the aggressive agent. This finding was also evidenced by Liu and Burne (2009) and by Wu et al. (2010).

In conclusion, $\left[\mathrm{W}^{7}\right]$ KR12-KAEK demonstrated antimicrobial and anti-biofilm activities against the selected bacterial strains, unlike the natural peptide KR-12. The factors that lead to the increased biological activity include peptide length, hydrophobicity and structure. Despite visual membrane changes, further studies on the mechanism of action and cytotoxic activity are necessary before an effective commercial product for the control and/or treatment of cariogenic infections can be developed.

\section{Disclosure statement}

The authors declare that they have no conflict of interest.

\section{Funding}

This work was supported by Fundação Cearense de Apoio ao Desenvolvimento Científico e Tecnológico (FUNCAP), Conselho Nacional de Desenvolvimento Científico e Tecnológico (CNPq), Coordenação de Aperfeiçoamento de Pessoal de Nível Superior (CAPES) and Central Analítica-UFC/CT-INFRA/ MCTI-SISNANO/Pró-Equipamentos CAPES. E. H. Teixeira is a member of the Brazilian Academy of Sciences.

\section{References}

Ambroggio EE, Separovic F, Bowie JH, Fidelio GD, Bagatolli LA. 2005. Direct visualization of membrane leakage induced by the antibiotic peptides: maculatin, citropin, and aurein. Biophys J . 89:1874-1881. doi:10.1529/biophysj.105.066589

Bahar AA, Ren D. 2013. Antimicrobial peptides. Pharmaceuticals. 6:1543-1575. doi:10.3390/ph6121543

Batoni G, Maisetta G, Brancatisano FL, Esin S, Campa M. 2011. Use of antimicrobial peptides against microbial biofilms: advantages and limits. Curr Med Chem. 18:256279. doi:10.2174/092986711794088399

Bjarnsholt T, Ciofu O, Molin S, Givskov M, Høiby N. 2013. Applying insights from biofilm biology to drug development - can a new approach be developed? Nat Rev Drug Discov. 12:791-808. doi:10.1038/nrd4000

Bowen WH. 2015. Dental caries - not just holes in teeth! A perspective. Mol Oral Microbiol. 31:228-233. doi:10.1111/ omi.12132

Bowen WH, Koo H. 2011. Biology of Streptococcus mutansderived glucosyltransferases: role in extracellular matrix formation of cariogenic biofilms. Caries Res. 45:69-86. doi:10.1159/000324598 
Brogden KA. 2005. Antimicrobial peptides: pore formers or metabolic inhibitors in bacteria? Nat Rev Microbiol. 3:238250. doi:10.1038/nrmicro1098

Brötz H, Bierbaum G, Leopold K, Reynolds PE, Sahl HG. 1998. The lantibiotic mersacidin inhibits peptidoglycan synthesis by targeting lipid II. Antimicrob Agents Chemother. 42:154-160.

Cespedes GF, Lorenzón EN, Vicente EF, Mendes-Giannini MJ, Fontes W, Castro MS, Cilli EM. 2012. Mechanism of action and relationship between structure and biological activity of Ctx-Ha: a new ceratotoxin-like peptide from Hypsiboas albopunctatus. Protein Pept Lett. 19:596-603. doi:10.2174/092986612800494011

Chan DI, Prenner EJ, Vogel HJ. 2006. Tryptophan- and argininerich antimicrobial peptides: structures and mechanisms of action. Biochim Biophys Acta (BBA)-Biomembranes. 1758:1184-1202. doi:10.1016/j.bbamem.2006.04.006

Chen Y, Mant CT, Farmer SW, Hancock RE, Vasil ML, Hodges RS. 2005. Rational design of $\alpha$-helical antimicrobial peptides with enhanced activities and specificity/therapeutic index. J Biol Chem. 280:12316-12329. doi:10.1074/jbc.M413406200

Clarke JK. 1924. On the bacterial factor in the aetiology of dental caries. Br J Exp Pathol. 5:141-147.

Crusca E, Rezende AA, Marchetto R, Mendes-Giannini MJ, Fontes W, Castro MS, Cilli EM. 2011. Influence of $\mathrm{N}$-Terminus modifications on the biological activity, membrane interaction, and secondary structure of the antimicrobial peptide Hylin-a1. Pept Sci. 96:41-48. doi:10.1002/bip. 21454

da Silva BR, de Freitas VA, Carneiro VA, Arruda FV, Lorenzón EN, de Aguiar AS, Cilli EM, Cavada BS, Teixeira EH. 2013. Antimicrobial activity of the synthetic peptide Lys-a1 against oral streptococci. Peptides. 42:78-83. doi:10.1016/j. peptides.2012.12.001

Futaki S, Suzuki T, Ohashi W, Yagami T, Tanaka S, Ueda K, Sugiura Y. 2001. Arginine-rich peptides. An abundant source of membrane-permeable peptides having potential as carriers for intracellular protein delivery. J Biol Chem. 276:5836-5840. doi:10.1074/jbc.M007540200

Hanioka T, Ojima M, Tanaka K, Yamamoto M. 2011. Does secondhand smoke affect the development of dental caries in children? A systematic review. Int J Environ Res Public Health. 8:1503-1519. doi:10.3390/ijerph8051503

Kalesinskas P, Kačergius T, Ambrozaitis A, Pečiulienė V, Ericson D. 2014. Reducing dental plaque formation and caries development. A review of current methods and implications for novel pharmaceuticals. Stomatologija. 16:44-52.

Kreling PF, Aida KL, Massunari L, Caiaffa KS, Percinoto C, Bedran TBL, Spolidorio DMP, Abuna GF, Cilli EM, Duque C. 2016. Cytotoxicityand the effect of cationic peptide fragments against cariogenic bacteria under planktonic and biofilm conditions. Biofouling. 32:995-1006. doi:10.1080/08 927014.2016.1218850

Liu Y, Burne RA. 2009. Multiple two-component systems of Streptococcus mutans regulate agmatine deiminase gene expression and stress tolerance. J Bacteriol. 191:7363-7366. doi:10.1128/JB.01054-09

Machado I, Lopes SP, Sousa AM, Pereira MO. 2012. Adaptive response of single and binary Pseudomonas aeruginosa and Escherichia coli biofilms to benzalkonium chloride. J Basic Microbiol. 52:43-52. doi:10.1002/jobm.v52.1
Merrifield RB. 1963. Solid phase peptide synthesis. I. The synthesis of a tetrapeptide. J Am Chem Soc. 85:2149-2154. doi:10.1021/ja00897a025

Mishra B, Epand RF, Epand RM, Wang G. 2013. Structural location determines functional roles of the basic amino acids of KR-12, the smallest antimicrobial peptide from human cathelicidin LL-37. RSC Adv. 3:19560-19571. doi:10.1039/ C3RA42599A

Patrzykat A, Friedrich CL, Zhang L, Mendoza V, Hancock RE. 2002. Sublethal concentrations of pleurocidin-derived antimicrobial peptides inhibit macromolecular synthesis in Escherichia coli. Antimicrob Agents Chemother. 46:605614. doi:10.1128/AAC.46.3.605-614.2002

Paulsen VS, Blencke HM, Benincasa M, Haug T, Eksteen JJ, Styrvold OB, Scocchi M, Stensvåg K. 2013. Structureactivity relationships of the antimicrobial peptide arasin 1 - and mode of action studies of the N-terminal, prolinerich region. PLoS ONE. 8:526-533. doi:10.1371/journal. pone.0053326

Richard JP, Melikov K, Vives E, Ramos C, Verbeure B, Gait MJ, Chernomordik LV, Lebleu B. 2003. Cell-penetrating peptides. A reevaluation of the mechanism of cellular uptake. J Biol Chem. 278:585-590. doi:10.1074/jbc.M209548200

Salli KM, Forssten SD, Lahtinen SJ, Ouwehand AC. 2016. Influence of sucrose and xylitol on an early Streptococcus mutans biofilm in a dental simulator. Arch Oral Biol. 70:3946. doi:10.1016/j.archoralbio.2016.05.020

Silva BR, Freitas VAA, Nascimento-Neto LG, Carneiro VA, Arruda FVS, Aguiar ASW, et al. 2012. Antimicrobial peptide control of pathogenic microorganisms of the oral cavity: a review of the literature. Peptides. 36:315-321. doi:10.1016/j. peptides.2012.05.015

Stepanovic S, Vukovic D, Dakic I, Savic B, Svabic-Vlahovic M. 2000. A modified microtiter-plate test for quantification of staphylococcal biofilm formation. J Microbiol Methods. 40:175-179. doi:10.1016/S0167-7012(00)00122-6

Subbalakshmi C, Nagaraj R, Sitaram N. 1999. Biological activities of c-terminal 15-residue synthetic fragment of melittin: design of an analog with improved antibacterial activity. FEBS Lett. 448:62-66. doi:10.1016/S00145793(99)00328-2

Tao R, Tong Z, Lin Y, Xue Y, Wang W, Kuang R, et al. 2011. Antimicrobial and antibiofilm activity of pleurocidin against cariogenic microorganisms. Peptides. 32:1748-1754. doi:10.1016/j.peptides.2011.06.008

Ulaeto DO, Morris CJ, Fox MA, Gumbleton M, Beck K. 2016. Destabilization of $\alpha$-helical structure in solution improves bactericidal activity of antimicrobial peptides: opposite effects on bacterial and viral targets. Antimicrob Agents Chemother. 60:1984-1991. doi:10.1128/AAC.02146-15

Wadia JS, Stan RV, Dowdy SF. 2004. Transducible TAT-HA fusogenic peptide enhances escape of TAT-fusion proteins after lipid raft macropinocytosis. Nat Med. 10:310-315. doi: $10.1038 / \mathrm{nm} 996$

Walsh T, Oliveira-Neto JM, Moore D. 2015. Chlorhexidine treatment for the prevention of dental caries in children and adolescents. Cochrane Database Syst Rev. 4:CD008457. doi:10.1002/14651858.CD008457

Wang G. 2008. Structures of human host defense cathelicidin LL-37 and its smallest antimicrobial peptide KR-12 in lipid micelles. J Biol Chem. 283:32637-32643. doi:10.1074/jbc. M805533200 
Wang G, Epand RF, Mishra B, Lushnikova T, Thomas VC, Bayles KW, Epand RM. 2012. Decoding the functional roles of cationic side chains of the major antimicrobial region of human cathelicidin LL-37. Antimicrob Agents Chemother. 56:845-856. doi:10.1128/AAC.0563q7-11

Wang W, Tao R, Tong Z, Ding Y, Kuang R, Zhai S, Liu J, Ni L. 2012. Effect of a novel antimicrobial peptide chrysophsin-1 on oral pathogens and Streptococcus mutans biofilms. Peptides. 33:212-219. doi:10.1016/j.peptides.2012.01.006

Wimley WC, White SH. 1996. Experimentally determined hydrophobicity scale for proteins at membrane interfaces.
Nat Struct Mol Biol. 3:842-848. doi:10.1038/nsb1096 $-842$

Wu C, Ayala EA, Downey JS, Merritt J, Goodman SD, Qi F. 2010. Regulation of ciaXRH operon expression and identification of the CiaR regulon in Streptococcus mutans. J Bacteriol. 192:4669-4679. doi:10.1128/JB.00556-10

Zhang M, Wei W, Sun Y, Jiang X, Ying X, Tao R, Ni L. 2016. Pleurocidin congeners demonstrate activity against Streptococcus and low toxicity on gingival fibroblasts. Arch Oral Biol. 70:79-87. doi:10.1016/j. archoralbio.2016.06.008 